\title{
BEYOND THE MONEY: A CASE STUDY ON THE BENEFIT OF HAND-DRAWING BATIK TO FEMALE BATIK WORKERS IN JARUM KLATEN REGENCY
}

\author{
Widhi Handayani, Augustinus Ignatius Kristijanto dan Arianti Ina Restiani Hunga \\ Universitas Kristen Satya Ẃacana \\ Email: widhyandayani@gmail.com
}

\begin{abstract}
ABSTRAK
Batik adalah produk budaya Indonesia dan diproduksi oleh industri rumahan berbasis Putting Out System (POS). Meskipun industri rumahan batik bermanfaat secara ekonomi, dampaknya terhadap lingkungan cenderung bersifat merusak disebabkan karena pencemaran air yang dihasilkan dari proses POS. Terlebih, produksi batik dengan POS dinilai merugikan pekerja rumahan perempuan. Tulisan ini bertujuan untuk menjelaskan manfaat industri batik di Desa Jarum, Klaten terhadap pekerja rumahan perempuan, bahkan seandainya polusi air terjadi di desa tersebut. Industri batik memberikan manfaat karena menyediakan lapangan kerja bagi pekerja rumahan perempuan di Desa Jarum. Sayangnya, manfaat produksi batik belum sepenuhnya dirasakan oleh beberapa pekerja rumahan perempuan karena upah yang rendah selain pencemaran yang berisiko mencemari air sumur yang digunakan untuk aktivitas domestik. Pada akhirnya, manfaat batik tidak hanya dibatasi oleh konteks ekonomi, karena batik menyediakan ruang untuk aktualisasi diri, khususnya bagi para pembatik tua.
\end{abstract}

Kata Kunci: Batik; Lingkungan; Manfaat; Pekerja rumahan; Putting out system.

\begin{abstract}
Batik is a cultural product of Indonesia and it is produced by home industries under Putting Out System (POS). Although batik home industries are beneficial economically, their impacts on environment tend to be destroyed due to water pollution resulted from the process of POS. Moreover, batik production by POS is considered to disadvantage female homeworkers. This paper aims to explain the benefit of batik industries in Jarum Village, Klaten toward female homeworkers, even if water pollution occurs in the village. Batik industries give benefit because they provide employment for female homeworkers in Jarum Village. Unfortunately, the benefit from batik production not yet received by some female homeworkers due to low wages they get, in addition to the pollution which could contaminate the groundwater they use for domestic activities. Finally, batik benefits are not merely regarding economics context as batik provides a space for self-actualization, mainly to the elder workers.
\end{abstract}

Keywords: Batik; Benefit; Environment; Homeworkers; Putting out system. 


\section{INTRODUCTION}

The micro and small-medium enterprises (SMEs) are considered to be an economic booster in developing countries. This is by no exception to batik, which brings positive impact economically by increasing the income of Indonesia by the increase of batik demand. It is reported that in 2006 to 2010, batik demand for purchase to The United States, Belgium, and Japan was increasing to $56 \%$ or equal to USD 69 millions. Moreover, batik home industries open employment for unemployed people. Those benefits offered by batik home industries lead the government to expect that batik will be an economic booster in 2025 (Kementerian Perdagangan Republik Indonesia, 2011).

However, the benefits offered by batik home industries are not in line with its impact on the environment, as the industries tend to show environmental pollution. Synthetic dyes used for batik production are reported to cause river pollution in Pekalongan, Sragen, Klaten, and Sukoharjo (Lucas, 2002; Kristijanto et al., 2013; Ahmad et al., 2010; Kurniawan et al., 2013). In addition to the colored water and other changes of water properties such as its odor and taste, polluted water causes itch in children (Ahmad et al., 2010). The pollution is considered to be resulted from the use of synthetic dyes, which are reported to cause skin irritation on batik workers (Soebaryo, 2012).

The impact of batik is not merely regarding environmental context, but also on female homeworkers. The hand-drawn batik or batik tulis is associated with womanhood and femininity as it involves diligence and carefulness in its making process. The handdrawn batik is usually produced under the so-called Putting Out System (POS) or a subcontracting production system. It is a system which involves homeworking activities and homeworkers as a part of the process (Fajerman, 2014). POS brings opportunity to the businessmen to put the risk of rejected product on homeworkers where the homeworkers should be responsible for the rejected product by making products which fulfill the quality standard (Hunga, 2014). Furthermore, the electricity and equipment costs are of responsibility of the homeworkers (Fajerman, 2014). In the batik context, batik female homeworkers are paid by low wages and their homes are turned into slum factories that might affect the health of the workers' family (Hunga, 2014). In brief, POS is considered to put disadvantages on female batik homeworkers.

As explained above, hand-drawing batik is associated to women. Nevertheless, batik production under POS is considered to disadvantage female batik workers. Therefore, this study will explain the benefits of batik production for Jarum Villagers. Included in the study is explanation whether batik industries benefit the female workers or not, even if pollution threats Jarum Village. The theory used for this purpose is Maslow's theory of motivation.

Moreover, as batik production shows adverse effect both to the environment and to women at once, ecofeminism theory will also be used in the analysis. This theory states that the ideology which authorizes oppressions such as those based on race, class, gender, sexuality, physical abilities, and species, is the same ideology which sanctions the oppression of nature (Gaard, 1993). This view distinguishes two classes, i.e. upper class and oppressed class. In this case, the upper class is represented by batik industries, while the oppressed class is represented by female batik homeworkers and the physical environment.

As we explained previously, batik production under POS is considered to put disadvantages to female batik workers, in which the disadvantage is strongly related to wages or income issue. This research could provide an insight on the meaning of batik to the female batik workers, which is not merely limited to income. This information could describe that batik preservation should not be done because it offers employment or additional income to the workers. Instead, batik has a meaning or a value to the female workers, in which money could not replace it. 
This research was conducted in Jarum Village, Klaten Regency in 2016, and is part of interdisciplinary study focused on environmental issue. Jarum was selected as a case study site based on three considerations: (1) Jarum is a batik center which has been assigned as a tourism village by the government of Klaten Regency in 2014 (Harwanto, 2014); (2) Jarum differs from other batik centers such as Pekalongan, Sukoharjo, and Sragen, environmental issues have not yet reported to occur in this village. Hence, it will be interesting to conduct the study in this village in order to provide information as preventive study rather than to overcome a bigger environmental problem occurs in other batik centers; (3) the villagers get the water for their domestic as well as industrial activities mainly from the dug wells. If (water) pollution takes place in the village, in a long term the villagers can suffer from the risk of water scarcity when the pollutants contaminate the wells.

Based on our previous research, there are 31 batik industries in the village, 19 of which produce batik cloth, 10 industries produce batik on woodcraft, an industry produces batik on T-shirt, and another industry produces batik paintings (Handayani et al., 2017). However, we focused on batik cloth production as female homeworkers get involved in hand drawing batik, and that batik cloth industries comprise about $61 \%$ of total batik industries in Jarum.

Participatory Action Research method in combination with case study approach was used for this qualitative research. The data was collected from entrepreneurs of seven batik home industries in Jarum Village. Based on local criteria, five of those industries are classified into large industries, one of which is a small industry, and the rest is a moderate-scaled industry (Handayani et al., 2017). In the next discussion, the batik entrepreneurs will be called as juragan. They could be considered as businessmen if they label their products by their own labels and determine the price of the products by themselves, or workers if they are just doing production by orders where they do not put the label of their SMEs on the ordered products (Hunga, 2014). Hence, in this case, juragan could act as both businessman and labor either. Other informants were batik workers or those who work to juragan in order to get paid. There were ten batik workers, both male and female workers from whom we get data regarding the benefit of batik industries and environmental issue related to batik production. Additional information collected from farmers and housewives who lives in Jarum.

Data regarding the benefit of batik industries and the environmental issue was collected by 30 minutes to an hour interview. The interview was recorded and transcripted before further analysis. Additional data was collected by observation, mainly on environmental problems resulted by batik production. Triangulation was used to ensure data validity. Data analysis was conducted by data reduction and classification, and finally, the result is presented in narrative form. In order to keep the safety of the informants, we present them by different pseudonyms.

\section{DISCUSSION}

\section{The Batik Workers: Buruh Harian And Buruh Borong Lepas}

Our study found that batik workers could be classified into two categories. The first is buruh harian or they who work to juragan and are paid on daily basis. The second is buruh borong lepas or they who work to Juragan and are paid per piece of cloth produced. Based on our observation, buruh harian was represented by workers who do their job in the house of juragan and are paid per day. The workers who are responsible for coloration, the male workers (Figure 1), are a good example of buruh harian. In addition, there were batik female workers who do their job in juragan's home and were paid on daily basis. The buruh borong lepas was represented by batik workers who were paid per piece of batik cloth they draw.

The female batik workers might do their job in the juragan's home (Fig. 2) or in their homes (Handayani et al., 2018b). Commonly, 


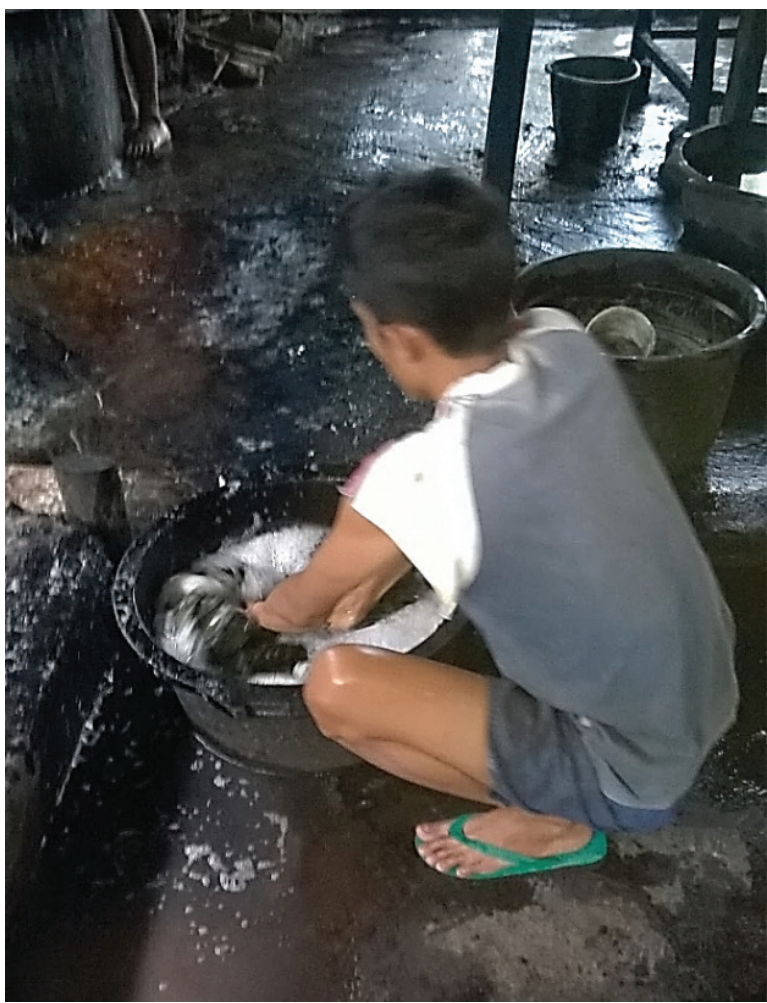

Figure 1

A male batik worker is doing color fixation in juragan's home

Picture source: personal documentation, 2016

those who work in juragan's home have no responsibility in taking care of their children. They used their time to hand draw batik for finishing process (nembok) and went home in the afternoon to do housework. The experience of Ibu Daryanti as explained below is a good example.

Ibu Daryanti was a 49 years old woman who has been six years working for Sarwo Adi Batik. She hand-draws batik since her childhood. In her memory, her first exercise was folding the finished batik clothes. Her mother and older relatives taught her to draw lines using a canthing, a traditional tool used to hand draw batik. She was usually sitting around the frypan, which is usually used to melt the wax for batik, together with the more expert hand drawers while looking at the isen-isen (ornaments) they draw. This way helps her to know the name of isen-isen and to imitate in drawing the isen-isen, although she was not yet perfect in doing that. By the time, she knew how to draw variants of isen-isen, such as kembang pari, kembang suruh, kembang kluwih and other kinds of isen-isen. In doing her job, she was usually arrived at 07.30 in the morning at the juragan's home to hand draw batik (nembok) with her nine friends. She could finish three to five pieces of batik clothes per day depend on the motifs. For some complicated motifs, she could get three clothes, while for simpler motifs, she could get more clothes. Nevertheless, in a day, she could get at least four clothes to finish. She was paid for IDR 10,000 per piece of cloth, and as she could finish four clothes per day, this means that she could get IDR 40,000 per day. She enjoyed her job and was not interested to take her job at home because of the weakness of her body. She used to draw batik at home when she was young and when she had to do her job over time. As she was getting older, she refused to hand draw batik at home. (Daryanti, interview on 2016)

The batik workers sat on a short stool or dingklik in Javanese word, around the frypan and faced the cloth put upon gawangan, a tool like a soccer goal upon which the cloth is put. A stove was used to melt the wax and the liquid wax is used to draw motifs on the cloth. Generally, gas was used for fuel, however, it depends on the juragan, whether the gas or fuelwood will be used as the fuel for the stove.

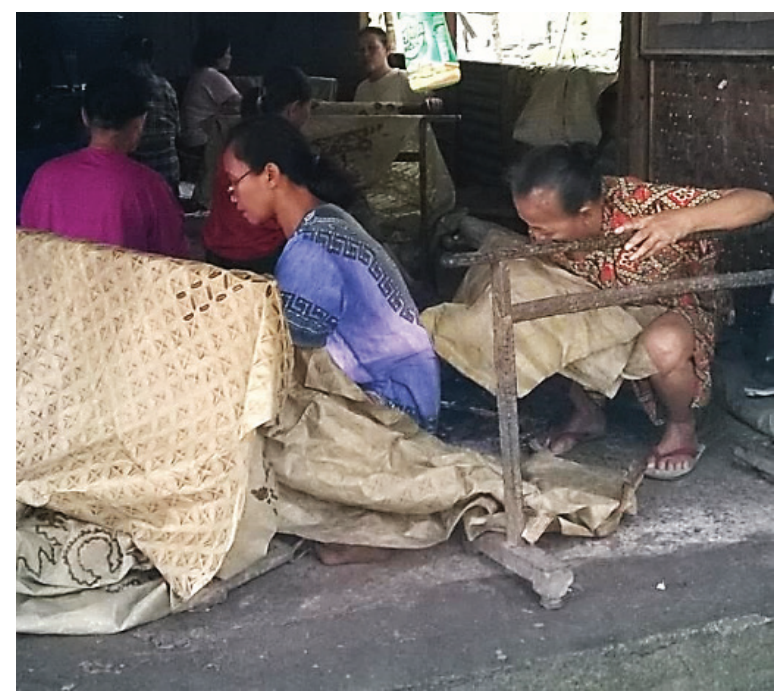

Figure 2

Batik workers are drawing batik at the juragan's home

Picture source: personal documentation, 2016

Those female batik workers who worked in juragan's home were more than 40 years old, and their children have got married. When they were young, they used to work at 
home as pembatik putihan whose job is hand draw pattern on white clothes. Nembok or the finishing process was regarded to be much easier than mutih, a process of hand draw the pattern or the first stage of making batik. To those elder workers, making batik was not merely to gain income, but also for their pleasure. Moreover, they received IDR 40,000 to 50,000 per day from batik.

Ibu Marsinah was a 54 years old woman who works for Sarwo Adi Batik. She joined juragan since he started his business in 2006. She could get five pieces of batik clothes per day and she was paid per piece of cloth she finished. She enjoyed her job as the juragan provides her flexibility on how many hours she would do her job. However, she was always come to the juragan for at least five hours of her leisure time. She used to do muth when she was young. However, along with her age, she was not interested to do mutih at home and hence, she decided to work at the juragan. She enjoyed in making batik at the house of juragan because she could meet her friends in addition to getting income.

"Kula sampun dangu awit taksih gadhah mori satus, paribasane. Kula pertama teng ngriki. Taksih ijal-ijal, wiwit daune sing kangge warna dereng tumbas, taksih pados, turut lepen-lepen niku. Paribasane taksih wonten ta? Taksih pertama. Wiwit mori sepuluh, rongpuluh, mindhak-mindhak ngantos mori samenten niki. Awit alit, anak-anak, ngantos anake entek yo tetep mbathik." (Marsinah, interview on 2016)

However, not all batik workers do their job at juragan's home. Some of them also work at their homes. A good example of this was Ibu Nurati, a 70 years old woman who works for Pertiwi Batik (Figure.3). She was usually hand drawing mutih for Ibu Prapti (the owner of Pertiwi Batik) and was usually paid for IDR 25,000 for each putihan she finished. In doing her job, she did not rely on just to her skill but she has to prepare canthing, frypan, and stove by herself, while wax and cloth were provided by juragan. Hunga (2012) wrote that female batik worker is usually not bound by a contract to her juragan, and this means that she could be both fired by the juragan or resign from her juragan, every time.

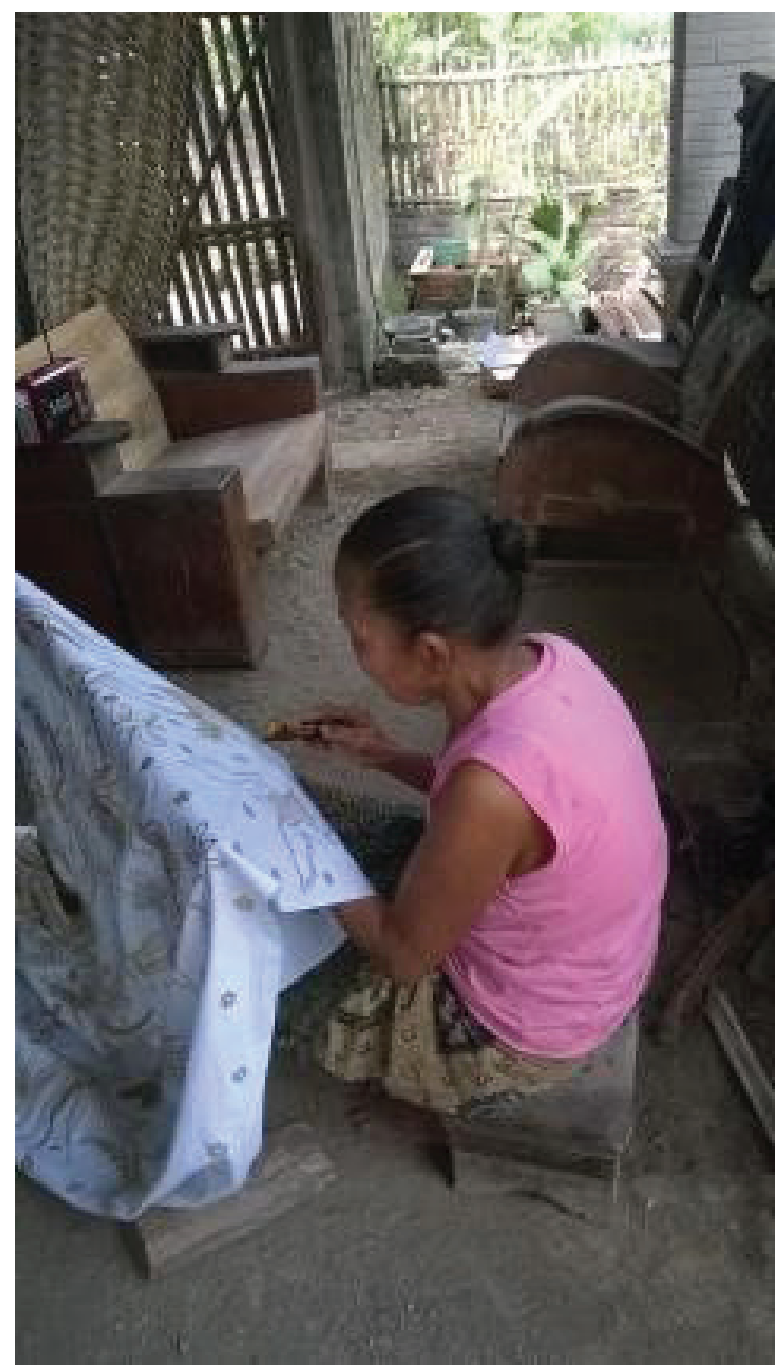

Figure 3

A batik homeworker is drawing batik at home Picture source: Handayani et al., $2018 b$

There were differences in term of the wages for batik workers and this depends on the juragan. Pak Ardi, juragan of Sarwo Adi Batik pays his pembatik putihan depends on the quality of their hand drawing. A putihan of premium quality will be paid of IDR 95,000 while the lower quality is paid for IDR 60,000 and the lowest quality is paid for IDR 40,000 . He pays IDR 50,000 per piece for pembatik tembokan, such as Bu Daryanti and Bu Marsinah. 
Table 1

The wages of batik workers of different Juragans

\begin{tabular}{|c|c|c|c|c|c|c|c|}
\hline \multirow[t]{3}{*}{ No. } & \multirow[t]{3}{*}{$\begin{array}{l}\text { Name of } \\
\text { Juragan }\end{array}$} & \multirow[t]{3}{*}{$\begin{array}{c}\text { Batik-based } \\
\text { product }\end{array}$} & \multirow{3}{*}{$\begin{array}{c}\text { The scale of } \\
\text { batik home } \\
\text { industry }\end{array}$} & \multicolumn{3}{|c|}{$\begin{array}{l}\text { Wages of batik worker } \\
\text { (in thousand IDR) }\end{array}$} & \multirow[t]{3}{*}{ Data source } \\
\hline & & & & \multicolumn{2}{|c|}{ Per day } & Per piece & \\
\hline & & & & $\begin{array}{c}\text { Ngobati } \\
\text { (coloration) }\end{array}$ & $\begin{array}{l}\text { Nyanthing } \\
\text { (hand draw } \\
\text { batik) }\end{array}$ & $\begin{array}{l}\text { Nyanthing } \\
\text { (hand draw } \\
\text { batik) }\end{array}$ & \\
\hline 1. & Mardiyanti & T-shirt & Large & 50 & 50 & $10-100$ & Handayani \\
\hline 2. & Prapti & Cloth & Large & 75 & 50 & 25 & et al., 2017 \\
\hline 3. & Suprayitno & Pillowcase & Large & 25 & 25 & $30-100$ & This study \\
\hline 4. & Suharyono & Clothes & Large & 50 & 25 & $60-400$ & This study \\
\hline 5. & Ardi & Cloth & Large & $25-50$ & --- & $10-100$ & This study \\
\hline 6. & Suwitono & Cloth & Moderate & --- & --- & $35-50$ & This study \\
\hline 7. & Nurseno & Cloth & Small & --- & --- & $25-150$ & This study \\
\hline
\end{tabular}

Another juragan, Pak Suprayitno would pay perempuan pembatik in a range of IDR 30,000 to IDR 100,000 per each putihan based on the hand drawing quality and the cloth used for making batik. It is generally known that silk is usually more expensive and more complicated to be batiked than cotton and they who work with silk will be paid higher than those of with cotton. Table 1 presents the wages of batik workers of different Juragans.

Based on Table 1, there were differences among juragans in paying their workers. $J u$ ragans of large home industries employed buruh harian besides buruh borong lepas. Juragans of moderate and small home industries employed buruh borong lepas and they did not yet employ buruh harian. The latter juragans were responsible to do coloration by themselves and they did not pay themselves for doing that job.

Workers for coloration or the dyers were paid for IDR 25,000 to IDR 75,000 per day or IDR 50,000 per day on average, while buruh nyanthing were paid of IDR 25,000 to IDR 50,000 per day or IDR 37,500 per day on average (Table 1.). Those who work in coloration were considered to work harder than those who do nyanthing, and they were paid differently due to this reason (Handayani et al., 2017). We observed that in addition to coloration, the workers were responsible for boiling and washing the clothes and put them under the sunlight for drying (Figure 4). It seems that the male workers rely on their

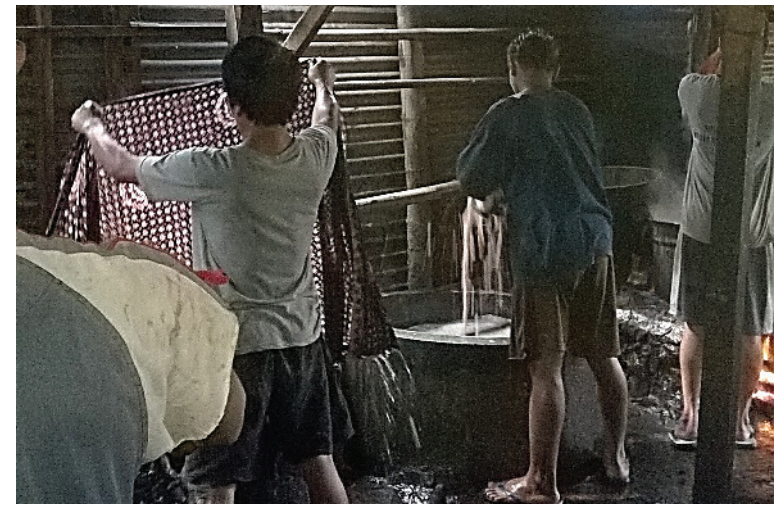

Figure 4

Batik coloration workers are washing the cloth at juragan's home

Picture source: personal documentation, 2016

physical strength while the females rely on their focus and thoroughness.

Although coloration was mostly done by male workers, we found females who do coloration tasks. Those women were of 4045 years old and they focused themselves in doing natural coloration to produce batik. However, this doesn't mean that all female workers were interested to do coloration. When Ibu Marsinah was asked if she wanted to do coloration, she directly refused as she thinks that it is uneasy for her to do the corresponding task.

\section{The Self-Employment}

Besides the buruh borong lepas, there was the self-employment. The self-employment is a batik worker who prepares materials for 
drawing batik including wax and white fabric which are usually provided by juragan and doing mutih on the cloth. We found a selfemployment who buy cotton cloth and pay a tukang gambar (a person whose job is drawing a pattern on the cloth by pencil), doing mutih at her home, and sell her work to juragans around her home.

Ibu Darmini was a 35 years old woman and she has two children. Her daughter was a student of grade $8^{\text {th }}$ in Junior High School, while her son was a student in kindergarten. Her husband was a siomay snack seller in Semarang. Darmini worked as a pembatik to get income for fulfilling the daily needs of her family. She used to work to Suratno, a juragan near her home and she was usually hand drawing batik at his home. However, Suratno fired her as she had to look after her son and this is why she makes batik at home. She usually buys a piece of white cotton cloth in size of $2.5 m \times 1.15 \mathrm{~m}$ for IDR 50,000. Then, she asks a tukang gambar from Trukan, Banyuripan, or Jarum to draw batik pattern on the cloth. She hand draws the pattern at home and after it is finished, she sells the cloth to juragan for IDR 70,000 or IDR 80,000. However, she felt that her job as a self-employment was not enough to fulfill her needs.

"Pait banget nyambut gawe ngene iki. Golek 50 ewu wae angel. Kadang wis nggawe, ning isih dipaido." (Darmini, interview on 2016)

Ibu Daryanti, Ibu Marsinah, Ibu Nurati, and Ibu Darmini, they are all batik female workers. Ibu Daryanti and Ibu Marsinah hand-drew batik at juragan's home and they enjoyed their jobs. Both Ibu Nurati and Ibu Darmini hand drew batik at their homes, however, Ibu Nurati enjoyed her activity while Ibu Darmini did not.

\section{Hand-Drawing Batik: What Does It Mean?}

In different to Ibu Darmini, the three female workers were elderlies who have no more responsibility to take care of their children, because their children have got married. They have ever passed the situation faced by Ibu Darmini when they were young. At that time, they had to work overtime at home to do mutih together with taking care of children. However, that situation was over. It seems that hand-drawing batik for them is a pleasure or an activity to pass their leisure time. Hand-drawing batik offers an opportunity for Ibu Daryanti and Ibu Marsinah to meet their neighbors and friends. They absolutely need income, but the income is needed only for their household and not for their children because the latter is now selfsufficient. Moreover, they were now being taken care by their children, as the case of Ibu Nurati.

The situation faced by those three were different to Ibu Darmini who has to look after her children and ensure their education, while her husband works in Semarang. Moreover, juragan doesn't want her to work at his home with her son. Hence, a flexible relationship without contract put her to be fired by the juragan. Being a self-employment was hard for her as she has to provide materials for making batik by herself and sell the cloth to juragan who wants to buy. When Juragan does not want to buy her cloth, she will receive no money. Hand-drawing batik for young ladies is a job to get money, indeed. Nevertheless, for elder workers, hand-drawing batik is a pleasure: leisure time activity which offers an opportunity to meet friends, neighbors, and relatives, as good as for producing money.

\section{The Impact of Batik Production on Environment}

While hand drawing batik was not yet a promising job for Ibu Darmini, pollution caused by batik industries put a heavier burden on her shoulders. The pollution resulted by batik production has been reported by Handayani et al., (2018a) and it corresponds to the batik wastewater characteristics which exceeds the quality standard set by the Indonesian government and The World Bank.

She and her family were irritated by the odor released by batik wastewater. Moreover, the wastewater might infiltrate to the ground and pollute the groundwater. If this situation occurs, she will suffer from double burden because 
water is required for household activities which of her responsibility, and her family relies on the well in order to get fresh water.

"Nggih nek ibarate, limbah itu ada, bau terus. Kemungkinan itu malah mau diprotes. Kemarin kan sudah bilang masalah itu, [jawabnya juragan] nggak papa ini. Cuma kan airnya itu kan mblèbèk terus Mbak ke jalanan itu. Lha kan becek ta, belakang itu, ya nggak papa dibuang ke kali aja, ya tetep aja bau. Akhirnya ya kalau mau, protes, sekitar sini itu harus protes. Kemungkinan setahun sekali bisa memberi sembako apa-apa gitu kalau punya kesadaran ya, juragan kaya itu. Tapi nggak pernah. Itu yang dikeluhkan yang dekat sini. Itu dikeluhkan". (Darmini, interview on 2016)

As SMEs in general, micro and small batik home industries are assumed to be beneficial as they provide employment and reduce unemployment, and bring more income. However, not all people feel the benefit of batik industries. In similar to Ibu Darmini, issue of pollution was revealed by Ibu Suminten, a housewife who lives around the river. According to her, the pollution should be the responsibility of both juragan batik and the pig farmer. Nevertheless, she thought those two have been doing nothing to overcome the problem, even she felt that she gets nothing from juragan. Her argument was similar to that of Ibu Darmini. To them, beneficial means they could get something to sustain their life. Although the pig farmer pollutes the river, they revealed that he has ever shared his wealth in the form of sembako (nine basic commodities for household, i.e. rice, corn, soybean, sugar, cooking oil, beef, onion, chicken meat, and eggs) to them.

The pollution was actually not faced only by Ibu Darmini and Ibu Suminten, but also by Ibu Nurati. The latter also complained the pollution and even she has ever reminded the juragan due to the situation, although she was ignored by the juragans. Interestingly, Ibu Nurati did not expect to get sembako that Ibu Darmini and Ibu Suminten ask for. It might be possible that Ibu Nurati has been received the benefit of batik in the form of job and this could be the reason that she doesn't ask for another benefit of another form. What she expected is that she and other villagers are not affected by the pollution resulted from the wastewater.

Another respondent was Bapak Suhargo, a farmer who lives around the river. He confirmed that batik wastewater releases odor which is annoying the people. However, he considered batik home industries are beneficial to him and the villagers due to the employment they provide.

As it has revealed by Hunga (2014), batik is produced by Putting Out System which employs female homeworkers. Based on the ILO convention in 1996, homeworker is defined as a person who carries out work in his or her home or in other premises of his or her choice, other than the workplace of the employer; for getting remuneration which results in a product or service as specified by the employer, irrespective of who provides the equipment, materials or other inputs used (Fajerman, 2014). ILO (2015) noted that homeworkers are employed by industries mainly to increase their business efficiency. This is also explained by Nakabayashi (2017) who reported the advantage in using subcontracting weavers to save costs (loom and facilities maintenance costs, wages, recruitment costs, and other expenses to employ female workers), no requirement to train female workers, and no requirement to retain slack female workers.

Our study found that, besides the homeworkers who do their job at their homes, there are batik workers who do their job at juragan's home. The workers we found did their job without any official contract to their juragans. This result is also found in batik homeworkers in Pekalongan, as reported by ILO (2015). The homeworkers are not interested in using the official contract as they unlikely want to be bound only to a juragan. Without any official contract, they could work for more than a juragan in order to get more income (ILO, 2015). Working with two or more juragans might give them a security, as if they resign from a juragan, they could still work to another juragan in order to get income. 
Regarding the remuneration, batik workers might be paid daily or per piece basis. The dyers were paid daily, while buruh nyanthing might be paid per piece or per day. If it is converted in monthly income, the dyers would get IDR 1,250,000 per month, while buruh nyanthing would get IDR 937,500 per month in the assumption that all of them work 25 days per month.

Remuneration based on per piece was usually divided into two categories, the first is mutih or hand-drawing batik pattern, and the second is nembok or finishing. Generally, mutih is a more complicated job than nembok, and as consequence, the workers for mutih is paid higher than nembok. Our study found that the workers were paid for IDR 25,000 to IDR 100,000 for mutih a cotton cloth, or IDR 62,500 on average per piece of cotton cloth (Handayani et al., 2018b). If they could finish two pieces per week or equal to eight pieces per month, they will get IDR 500,000 per month. In regard to nembok, the workers were usually paid for IDR 10,000 per piece and if in one day they could get four pieces, this means they could take IDR 40,000 per day. Assumed they work for 25 days, this means they would get IDR 1000,000 per month. This reveals that batik workers who do mutih are paid at the lowest while workers for nembok will get higher wages. The range of wages for batik homeworkers in Jarum is IDR 500,000 per month to IDR 1,000,000 on average.

Unfortunately, this range of wage is less than the Minimum Regional Income of Klaten Regency of IDR 1,400,000. ILO (2015) describes the wages of batik homeworkers is in the range of IDR 750,001 to IDR 1,000,000, and a minimum wage of less than IDR 250,000 found to be received by batik homeworkers in Pekalongan. In comparison to this report, batik homeworkers in Jarum Village get IDR 500,000 to IDR 1,0000,000. Nevertheless, they who work as self-employment could get lower income for just IDR 15,000 to IDR 20,000 per putihan they made. As the Minimum Regional Income of Klaten regency is IDR $1,400,000$, this means that the wage of batik workers in Jarum Village is still below the correspond regional income.

Some lessons learned from the results will be explained further. First, although batik industries provide employment, not all people feel to get benefit from them. The statement of Ibu Darmini describes the difficulty of getting money from making batik. Moreover, her position as self-employment is more vulnerable than batik workers who join the Juragan. Batik home industries are not yet beneficial to her as they cannot ensure her to sustain her life. Second, the batik wastewater rises a problem regarding pollution and health. The pollution annoys the villagers, and even put the risk this contamination to the groundwater they rely on for domestic activities. This indicates that the access of the villagers to juragan in decision making was blocked, particularly regarding the discharge of wastewater. The protest which is going to be done by some people indicates their effort in order to claim the control over the resource they usually access. The pollution risks their life, and this is why they demand sembako as a social responsibility of juragan, in order to sustain their life. Nevertheless, this could be criticized as providing sembako does not make sense in reducing pollution. Moreover, if the water becomes scarce due to the pollution, sembako would not replace the function of the fresh water.

Water pollution will absolutely show the impacts on the people, both men, and women. However, women will be suffered from this situation for the water related-domestic activities they have to handle. UNEP (2004) wrote that in most communities, women and children collect water per liter for cooking, bathing, washing, maintaining health and hygiene, raising small cattle, and planting vegetables. Based on gender role, women and men show the different part of using water. Moreover, the different situation between women of formal workers who work at institutions or companies ensured by official contract and batik workers will determine the adversity they would meet. They who work in formal sectors are guaranteed 
by monthly income, which means they could provide clean water from other sources if the groundwater is contaminated. The workers, as they couldn't get monthly income, rely on the water resource around them and water pollution put a heavier burden on them. This situation is as written by Hunga (2014) who wrote that female homeworkers bear the double burden as they have to take care of their family as housewives and being breadwinners at once.

The situation which suggests exploitation of workers and environmental destruction by batik industries is suited to ecofeminism theory as explained by Gaard (1993). This theory assumes there are two different classes, the first is upper class represented by the businessmen, and the lower class is represented by homeworkers and the ecosystem. The theory suggests the ideology which oppresses the environment is just the same to which that oppress women. It is the capitalism who work to get more benefits by letting environmental destruction occurs, while the destruction brings negative impact to the workers.

However, it should not directly be interpreted that female batik workers as the oppressed class are always care for the environment. Such interpretation could be misleading. Our finding shows that not all female batik workers care for the environment because it is intended to. The demand for sembako implies their interest in getting benefit which is unlikely related to environmental concern, and therefore, environmental awareness shall be questionable in this context.

Furthermore, it is important to note that batik is beneficial not only for the employment they provide. As it has been discussed previously, batik is a pleasure activity for elder batik workers. To them, hand-drawing batik provides a space where they could meet their friends and share the life they live. Hence, hand-drawing batik is not merely about money. It is about providing a space for self-actualization which is the highest need in the theory of Maslow (1943), and this could be achieved when the other needs, mainly of physical needs, have been fulfilled.

Commonly, there is an understanding that parents are responsible to grow up their children to be self-reliant people. In most households in Indonesia, children education takes the highest cost a household should spend. Hence, when the children finished their education, get employed, and get married this means parents' responsibility has been paid off.

This might be the reason that underlies the response of Ibu Daryanti, Ibu Marsinah, and Ibu Nurati. When they could fulfill their daily needs, and succeed in finishing their responsibility as parents, they might feel their life's purpose has been fulfilled. When it is compared to the Maslow's hierarchy, this means they have gained the needs for esteem and no more interest for them to get more money for their self-sufficient children. The money they work for will be used mainly to sustain their life. As the consequence, this might be no problem to them if they are low paid as far as their wage can afford their daily life. Thus, the benefit of batik should not be perceived only in the economic context of providing employment or producing money but also in the psychological context of providing a space for self-actualization.

\section{CONCLUSION}

Batik industries are beneficial to the Jarum villagers as they provide employment for the residence. However, not all female homeworkers feel that they are benefited from batik, as the wages they received are not sufficient to meet their daily needs. This situation gets worse as the pollution may lead to water scarcity that put a heavier burden on them. Nevertheless, the benefit provided by batik is not limited to employment and producing money. To young female workers, hand-drawing batik is a job in order to get income, indeed. However, to elder workers, hand-drawing batik means an activity in leisure time as well as an opportunity to meet friends, in addition to produce money. Finally, instead of just producing money, 
hand-drawing batik provides a space for selfactualization.

\section{ACKNOWLEDGEMENT}

The authors would gratefully acknowledge Biro Perencanaan \& Kerjasama Luar Negeri, Kementerian Pendidikan \& Kebudayaan Republik Indonesia, who supported this research by Beasiswa Unggulan Program Mandiri Scholarship in the year of 2015 No. 46287/A2.4/LL/2015. Acknowledgment is also addressed to Claudia Derichs and Philipps Universität Marburg-Germany who supported the writing of this article by STIBET-DAAD scholarship.

\section{BIBLIOGRAPHY}

Ahmad, R., D. Amalia, M. Haggerty, B.P. Putra, I. Pratomo, E. Schlickman, and J. Taylor. 2010. Colored Water: Assessment of Climate Change Vulnerability in Kelurahan Pabean, Pekalongan, Central Java. Jakarta: Center for Participatory Development Planning Services UN Habitat.

Fajerman, M. 2014. Review of the Regulatory Framework for Homeworkers in Indonesia. Jakarta: International Labour Office.

Gaard, G. 1993. Living Interconnections with Animals and Nature. In Gaard, G (Ed.) Ecofeminism: Women, Animals, Nature. Philadephia: Temple University Press.

Handayani, W., A.I.R. Hunga, and A.I. Kristijanto. 2017. "Penetapan Skala Industri Batik Rumahan menurut Kriteria Lokal: Studi di Desa Jarum, Kabupaten Klaten". Manajemen IKM 12 (1): 25-34.

Handayani, W., A.I. Kristijanto, and A.I.R. Hunga. 2018a. "Are Natural Dyes Eco-friendly? A case study on water usage and wastewater characteristics of batik production by natural dyes application". Sustainable Water Resources Management. 2018b. "Behind the Eco-friendliness of Batik Warna Alam: Discovering the motives behind the production of eco-friendly batik in Jarum village, Klaten". Wacana (in process of publication).

Harwanto, S. 2014. Kajian Wisata Seni Budaya Batik Berwawasan Lingkungan di Desa Jarum, Kecamatan Bayat, Kabupaten Klaten, Provinsi Jawa Tengah. Master Thesis, Yogyakarta: Institut Seni Indonesia.

Hunga, A.I.R. 2012. Menyingkap "Ketersembunyian" Home Workers dan Transformasi Putting Out System dalam Industri Mikro-Kecil-Menengah Batik: Studi kasus klaster industri batik di SragenSurakarta-Sukoharjo. Salatiga: Satya Wacana University Press.

Hunga, A.I.R. 2014. “Protecting Women's Domestic Area and Environment: Study on eco-friendly Batik". Indonesian Feminist Journal 2: 82-105.

International Labour Office (ILO). 2015. Penelitian tentang Praktik Pengusaha dalam Mempekerjakan Pekerja Rumahan di Jawa Barat dan Jawa Tengah. <http:/ / www.ilo.org/wcmsp5/groups/ public/---asia/---ro-bangkok/---ilojakarta/documents/publication/ wcms_438449.pdf $>$.

Kementerian Perdagangan Republik Indonesia. 2011. Miliki Potensi Ekonomi Tinggi, Mendag Serahkan Cetak Biru Pengembangan dan Pelestarian Batik ke Presiden. 28 September 2011. Press Release Pers Kementerian Perdagangan Republik Indonesia. Jakarta.

Kurniawan, M.W., P. Purwanto, and S. Sudarno. 2013. “Strategi Pengelolaan Air Limbah Sentra UMKM Batik yang Berkelanjutan di Kabupaten Sukoharjo". Jurnal Ilmu Lingkungan 11(2): 62-72.

Kristijanto, A.I., W. Handayani, and P.A.A Levi. 2013. "The Effectiveness of Anaerobic Baffled Reactor and Rotating 
Biological Contactor in Batik Wastewater Treatment". Makara Journal of Technology 15(2): 168-172.

Lucas, A. 2002. River Pollution and Political Action in Indonesia, in: Hirsch, P., \& P. Warren (Eds.). Politics of Environment in Southeast Asia. New York: Routledge.

Maslow, A. H. 1943. “A Theory of Human Motivation". Psychological Review 50: 370-396.
Nakabayashi, M. 2017. “Honesty, Diligence, and Skill: Risk sharing and specialization in the Kiryu silk weaving cluster, Japan". Review of Development Economics 21(4): 1401-1424.

Soebaryo, R.W. 2012. Batik Manufacturing Workers. In: Rustemeyer. T., P. Elsner, J. Swan-Malte, H.I. Maibach (Eds.) Kanerva's Occupational Dermatology. Heidelberg: Springer Verlag.

UNEP. 2004. Women and The Environment. Nairobi: UNEP Publisher. 